$\mathrm{A} \mathrm{J}_{\cos } \mathrm{H}$

Received : 20.10.2017

Revised : 17.11.2017

Accepted : 24.11.2017
Members of the Research Forum

Associated Authors:

${ }^{1}$ Department of Horticulture, Indira Gandhi Krishi

Vishvavidyalaya, RAIPUR (C.G.) INDIA

Author for correspondence : SARITA SAHU

College of Agriculture and

Research Station, RAIGARH

(C.G.) INDIA

Email : sarita.sahu2124@gmail.com

THEASIAN JOURNALOF HORTICULTURE

Volume 12 | Issue 2 | December, 2017 | 251-25

Visit us -www.researchjournal.co.in

RESEARCH PAPER

DOI : 10.15740/HAS/TAJH/12.2/251-254

\title{
Effect on storage behaviour of elephant foot yam under the influence of different pre-planting treatments
}

SARITA SAHU AND VIJAY KUMAR ${ }^{1}$

ABSTRACT : The experiment was conducted during the year 2010-11 and 2011-12 and the maximum weight loss per cent in corms was recorded at 90 days of storage i.e. 30.80 to 31.59 per cent and zero per cent rotting was noticed under almost all the pre planting treatments. Generally all tubers sprouted within 60 days of storage and a negligible increase at 90 days of storage.

KEY WORDS : Storage behaviour, Elephant foot yam, Pre-planting treatments

HOW TO CITE THIS ARTICLE : Sahu, Sarita and Kumar, Vijay (2017). Effect on storage behaviour of elephant foot yam under the influence of different pre-planting treatments. Asian J. Hort., 12(2) : 251254, DOI : 10.15740/HAS/TAJH/12.2/251-254. 